\title{
Structure of Hepatitis B Dane Particle DNA and Nature of the Endogenous DNA Polymerase Reaction
}

\author{
TERRY A. LANDERS, ${ }^{1}$ HARRY B. GREENBERG, ${ }^{2}$ AND WILLIAM S. ROBINSON* \\ Departments of Medicine and Biochemistry, Stanford University School of Medicine, Stanford, \\ California 94305
}

Received for publication 3 March 1977

\begin{abstract}
The circular DNA of hepatitis B Dane particles, which serves as the primer/ template for an endogenous DNA polymerase, was analyzed by electrophoresis before and after a polymerase reaction and after digestion by restriction endonuclease or single-strand-specific endonuclease S1. The unreacted molecules extracted from the particles were electrophoretically heterogeneous, and treatment with S1 nuclease produced double-stranded linear DNA ranging in length from 1,700 to 2,800 base pairs (bp). After an endogenous DNA polymerase reaction, two discrete species of DNA molecules were found: a circular form and a linear form $3,200 \mathrm{bp}$ long. The reaction resulted in a population of molecules with an elongated and more homogeneous double-stranded region. These results suggest that the circular molecules in Dane particles have single-stranded regions of varying lengths that are made double stranded during the DNA polymerase reaction. The endogenous DNA polymerase was found to initiate apparently at random in a region spanning more than a third of the molecule. Analysis of restriction endonuclease cleavage fragments of the fully elongated DNA revealed that although the molecules were of a uniform length, they were somewhat heterogeneous in sequence. The sum of the sizes of the 10 major endonuclease Hae III-generated fragments, detected by ethidium bromide, was $3,880 \mathrm{bp}$. Two additional fragments (B and G) detected by autoradiography after an endogenous DNA polymerase reaction with ${ }^{32} \mathrm{P}$-labeled deoxynucleoside triphosphates made the total $4,910 \mathrm{bp}$.
\end{abstract}

Although the infectious form of hepatitis $B$ virus (HBV) has not been identified with certainty, the Dane particle (5), which is one of the particulate forms of viral antigen found in the blood of infected patients, has properties suggesting that it is HBV. The ultrastructure of the Dane particle is consistent with that of a virus (5), the antigen on its surface appears to induce HBV-neutralizing antibody $(9,10)$, it has a unique internal core antigen (2), it is the only viral antigen form known to contain nucleic acid (20), its size (5) and usual numbers in serum (1) are consistent with the limited information about the size (12) and titer of infections HBV (4), and its concentration in the blood of infected patients appears to correlate with the frequency with which transmission of infection to patient contacts occurs $(3,14)$.

The core of the Dane particle, which can be prepared by treatment of Dane particles with a

\footnotetext{
${ }^{1}$ Present address: Department of Biochemistry and Molecular Biology, University of Texas Medical School, Houston, TX 77030.

${ }^{2}$ Present address: Laboratory of Infectious Diseases, National Institute of Allergy and Infectious Diseases, Bethesda, MD 20014.
}

detergent such as Nonidet P-40 (NP-40), contains a small circular DNA (17) and a DNA polymerase $(8,18)$. The only reaction so far shown to be catalyzed by the enzyme is DNA synthesis within the Dane particle core, utilizing the circular Dane particle DNA as a primer/template $(16,17,19)$. Summers et al. (23) recently suggested that the circular Dane particle DNA may contain a single-stranded region because it served as primer/template for avian myeloblastosis virus DNA polymerase, an enzyme unable to introduce radioactive nucleotides into preexisting double-stranded DNA. Hruska et al. (7) obtained more direct evidence for a single-stranded region by showing that the electron microscopic length of the circular DNA under conditions that extend single-stranded DNA was significantly greater than when the DNA was spread under conditions that do not extend such regions. The length was also increased after the endogenous DNA polymerase reaction, suggesting that the single-stranded gap was closed during the reaction.

In this study, we have examined the electrophoretic mobility of the DNA and analyzed re- 
striction endonuclease-generated fragments of the DNA before and after the Dane particle DNA polymerase reaction to further elucidate the structure of the DNA and the mechanism of the DNA polymerase reaction.

\section{MATERIALS AND METHODS}

Preparation of Dane particles. A $600-$ to $800-\mathrm{ml}$ amount of plasma from chronic hepatitis B surface antigen carrier 390 with high levels of Dane particle DNA polymerase activity (16) was clarified by centrifugation at 9,000 rpm for $15 \mathrm{~min}$. Dane particles were pelleted by centrifugation of the serum for $4 \mathrm{~h}$ at $21,000 \mathrm{rpm}$ in an SW21 rotor at $4^{\circ} \mathrm{C}$. The pellet was redissolved in about $15 \mathrm{ml}$ of TNEMBSA $(0.01 \mathrm{M}$ Tris-chloride, $0.1 \mathrm{M} \mathrm{NaCl}, 0.001 \mathrm{M}$ EDTA, $0.1 \% 2$ mercaptoethanol, and $1 \mathrm{mg}$ of bovine serum albumin per $\mathrm{ml}, \mathrm{pH}$ 7.5) to make a $\mathrm{P} 1$ preparation, which was stored at $-90^{\circ} \mathrm{C}$. To prepare Dane particles for a DNA polymerase reaction, 1 to $3 \mathrm{ml}$ of $P 1$ was pelleted through $30 \%$ sucrose in TNEMBSA by centrifugation for $4 \mathrm{~h}$ at $40,000 \mathrm{rpm}$ in an SW40 rotor at $4^{\circ} \mathrm{C}$. The pellet was redissolved in $200 \mu \mathrm{l}$ of $0.01 \mathrm{M}$ Tris-hydrochloride ( $\mathrm{pH}$ 7.5)-0.1 M NaCl-0.5\% NP40-0.1\% 2-mercaptoethanol $(\mathrm{pH} 7.5)$ to make an NP-40-P2 preparation.

Dane particle DNA polymerase reaction. For synthesis of DNA by the endogenously primed DNA polymerase reaction, $50 \mu \mathrm{l}$ of triphosphate $\operatorname{mix}(0.2$ M Tris-hydrochloride [pH 7.5], $0.08 \mathrm{M} \mathrm{MgCl}_{2}, 0.23 \mathrm{M}$ $\mathrm{NH}_{4} \mathrm{Cl}, 1 \mathrm{mM}$ each dATP and dTTP, $2.5 \mu \mathrm{M}$ each $\alpha$ [ $\left.{ }^{32} \mathrm{P}\right] \mathrm{dGTP}$ and $\alpha-\left[{ }^{32} \mathrm{P}\right] \mathrm{dCTP}$ [New England Nuclear Corp.; each $\sim 130 \mathrm{Ci} / \mathrm{mmol}$ ) was added to $200 \mu \mathrm{l}$ of NP-40-P2 at $37^{\circ} \mathrm{C}$. For pulse synthesis and kineticsof-incorporation experiments, portions were pipetted into excess EDTA at the appropriate time. For pulse-chase labeling, unlabeled dGTP and dCTP were added to a final concentration of $0.2 \mathrm{mM}$ at the indicated time, and the reaction was continued for 3 h. For extensive DNA synthesis, the unlabeled dGTP and dCTP were added after $15 \mathrm{~min}$, and the reaction was terminated after $3 \mathrm{~h}$.

Isolation and purification of DNA from Dane particle cores. The DNA polymerase reaction mix or unreacted NP-40-P2 with a trace of DNA polymerase reaction mix added (to provide a radioactive DNA marker) was layered over $4 \mathrm{ml}$ of $30 \%$ sucrose in TNEMBSA, and the core particles were pelleted by centrifugation for $3 \mathrm{~h}$ at $50,000 \mathrm{rpm}$ in an SW65 rotor at $4^{\circ} \mathrm{C}$. The pellet was then digested either with Pronase (100 $\mu \mathrm{l}$ of $1 \mathrm{mg}$ of Pronase per $\mathrm{ml}$ in $0.01 \mathrm{M}$ Tris-hydrochloride, [pH 7.5]-0.01 M EDTA$0.1 \%$ sodium dodecyl sulfate [SDS]) for 1 to $2 \mathrm{~h}$ at $37^{\circ} \mathrm{C}$ or with proteinase $\mathrm{K}$ in $0.01 \mathrm{M}$ Tris-hydrochloride ( $\mathrm{pH}$ 7.5)-0.01 M EDTA-0.15\% SDS for $2 \mathrm{~h}$ at $56^{\circ} \mathrm{C}$. Proteinase $\mathrm{K}$ was the more effective enzyme. Some protein appeared to be very tightly associated with the DNA, and this could not be completely removed even by two cycles of digestion in SDS with proteinase $\mathrm{K}$ and phenol extraction. The ratio of absorbance at $260 \mathrm{~nm}$ to absorbance at $280 \mathrm{~nm}$ of the DNA used in the experiments reported here ranged from 1.25 to 1.70 . The digest was extracted twice with phenol and then layered on top of a 5 to $20 \%$ linear sucrose gradient containing $0.01 \mathrm{M}$ Tris-hy- drochloride ( $\mathrm{pH}$ 7.5)-0.1 M NaCl-0.001 $\mathrm{M}$ EDTA and centrifuged for $3 \mathrm{~h}$ at $50,000 \mathrm{rpm}$ in an SW65 rotor at $20^{\circ} \mathrm{C}$. Fractions were collected from the bottom of the tube, and the peak fractions of the homogeneously sedimenting $15 S\left[{ }^{32} \mathrm{P}\right] \mathrm{DNA}$ component (17) were pooled. The DNA was precipitated with 2 volumes of ethanol, pelleted, dried, and redissolved in 20 to 100 $\mu$ l of $0.01 \mathrm{M}$ Tris-hydrochloride ( $\mathrm{pH} 7.5)-0.001 \mathrm{M}$ EDTA.

Endonuclease digestions. Single-strand endonuclease S1 digestions were performed essentially according to Shenk et al. (21).

Approximately $0.1 \mu \mathrm{g}$ of Dane particle DNA and $0.2 \mu \mathrm{g}$ of carrier DNA (sonically treated salmon sperm DNA that had been heat denatured) were digested with $8 \mathrm{U}$ of nuclease S1 (Miles Laboratories) in $25 \mu \mathrm{l}$ of $30 \mathrm{mM} \mathrm{NaAc}, 1 \mathrm{mM} \mathrm{ZnAc}$, and 0.24 $\mathrm{M} \mathrm{NaCl}, \mathrm{pH} 4.6$, for $2 \mathrm{~h}$ at $37^{\circ} \mathrm{C}$. The reaction was terminated with $5 \mu$ l of precipitation $\operatorname{mix}(4 \mathrm{M} \mathrm{NaCl}$, $0.16 \mathrm{M}$ Tris base, and $0.6 \mathrm{mg}$ of yeast tRNA per $\mathrm{ml}$ ). The nucleic acids were precipitated with 2 volumes of ethanol for $2 \mathrm{~h}$ at $-20^{\circ} \mathrm{C}$. As a control, the conversion of simian virus 40 (SV40) form II DNA to fulllength linears was followed. The reaction with SV40 DNA did not go to completion reproducibly as expected because of the slow reaction rate with nicked DNA. However, the single-stranded carrier DNA was never seen on the gel, suggesting that singlestranded DNA was completely digested in all experiments.

The various restriction endonuclease digestions were carried out in the appropriate buffers for $2 \mathrm{~h}$ at $37^{\circ} \mathrm{C}$ with 0.05 to $0.1 \mu \mathrm{g}$ of DNA in $20 \mu \mathrm{l}$. The reactions were terminated by adding $5 \mu \mathrm{l}$ of $2.5 \%$ SDS, $1 \%$ 2-mercaptoethanol, $0.05 \%$ bromophenol blue, and $50 \%$ glycerol and incubating at $37^{\circ} \mathrm{C}$ for 10 $\mathrm{min}$. Restriction endonucleases used were $E c o$ RI (6), Hae III (13), Hinf (R. J. Roberts, personal communication), and Hin II (22).

Gel electrophoresis. Agarose gel electrophoresis was carried out in a horizontal apparatus using gels of 0.8 or $1.2 \%$ agarose. Gels were run for 18 to $22 \mathrm{~h}$ at 25 to $40 \mathrm{~V}$. Size markers were various known restriction endonuclease fragments of SV40 DNA. Acrylamide gel electrophoresis used vertical slabs (14 by 14 by $0.16 \mathrm{~cm}$ ) poured with a 3 to $7 \%$ linear gradient of acrylamide and run for $3 \mathrm{~h}$ at $150 \mathrm{~V}$. Electrophoresis buffer for both types of gels was $89 \mathrm{mM}$ Tris- 89 $\mathrm{mM}$ boric acid-2.5 mM EDTA. For agarose gels, 0.5 $\mu \mathrm{g}$ of ethidium bromide per $\mathrm{ml}$ was included. Acrylamide gels were stained after electrophoresis in $\mathbf{0 . 5}$ $\mu \mathrm{g}$ of ethidium bromide per $\mathrm{ml}$ in water for $30 \mathrm{~min}$. Gels were photographed through two Kodak no. 21 gelatin filters on Polaroid type 105 positive/negative film. In all figures of gels used for DNA electrophoresis, DNA migration was from top to bottom.

\section{RESULTS}

Agarose gel electrophoresis of whole DNA. The DNA extracted from Dane particle preparations before a DNA polymerase reaction appeared as a broad smear when electrophoresed on 0.8 or $1.2 \%$ agarose gels (Fig. 1A). After digestion with single-strand-specific endonuclease $\mathrm{S} 1$ to cut at any nicks and remove any 


\section{Without Dane Particle DNA \\ Polymerase Reaction}

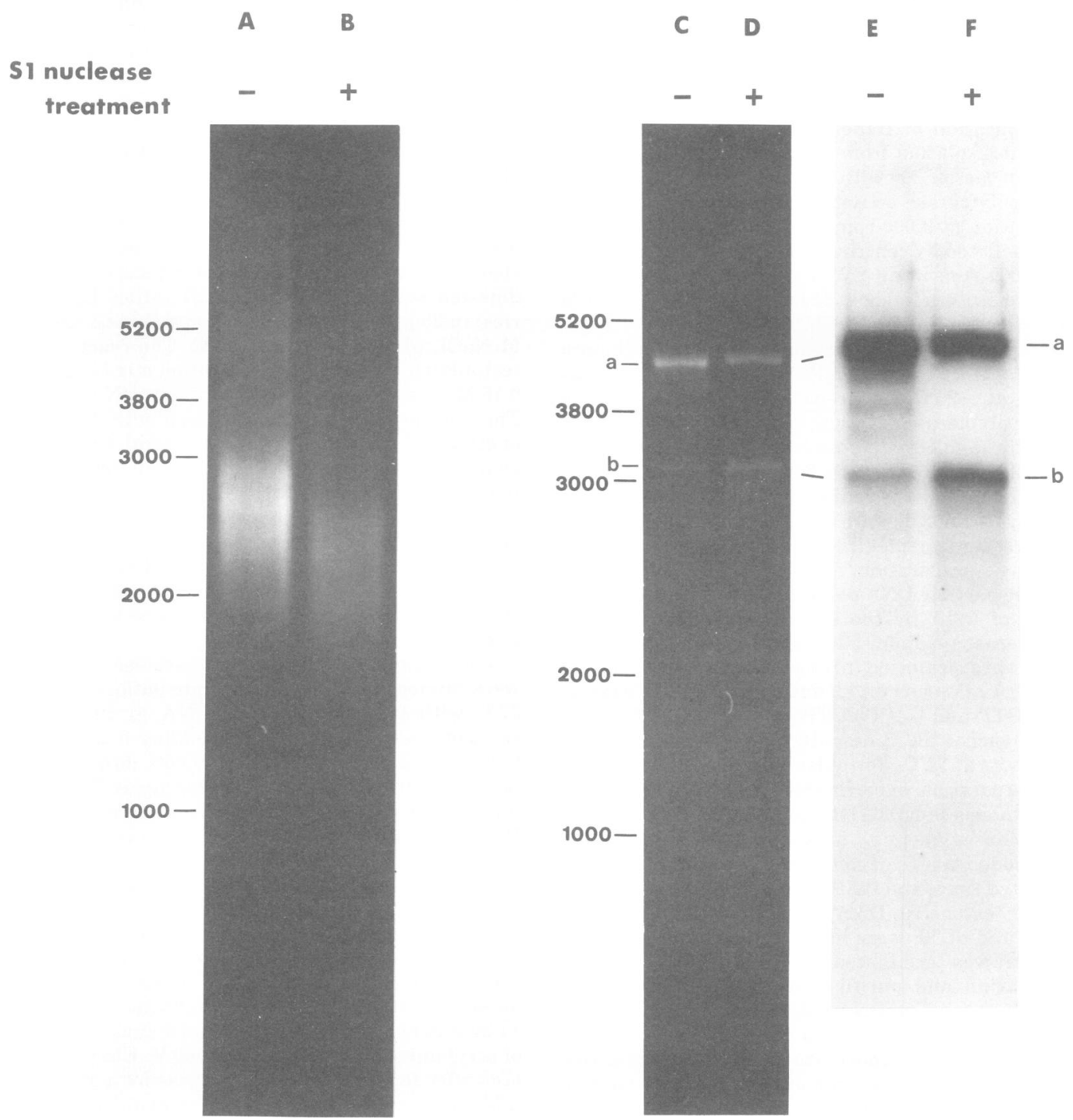

After Dane Particle DNA Polymerase Reaction

Fig. 1. Electrophoresis of Dane particle DNA. single-stranded DNA, the molecules were still heterogeneous and now migrated more rapidly (Fig. 1B), consistent with conversion from a circular to a linear form. The observations that the breadth of the ethidium bromide staining band was similar before and after nuclease S1 digestion and that none of the large amount of single-stranded DNA carrier was visible after digestion suggest that the nuclease $S 1$ reaction went to completion. The electrophoretic position of the S1-resistant DNA corresponded to the position of double-stranded linear DNAs ranging from less than 1,800 base pairs (bp) to greater than $2,700 \mathrm{bp}$, with a peak at about $2,400 \mathrm{bp}$.

After an endogenous DNA polymerase reaction, the DNA was found primarily in two discrete bands (designated $a$ and $b$ in Fig. 1C). When the polymerase reaction was carried out at reduced triphosphate concentrations, other bands were observed between the two major bands, traces of which are visible in Fig. 1E, the autoradiogram of Fig. 1C. Nuclease S1 digestion converted a portion of the slower- 
moving principal band (a) to the faster-migrating form (b), and all of the intermediate forms were shifted to positions ahead of the faster principal form (Fig. 1D and F). These results suggest that the slow main band (a) is a circular form, with only a small gap or nick, which is slowly converted to the linear form of the faster main band (b) by nuclease S1. The intermediate forms apparently have larger gaps since they are more readily converted to a linear form. The principal linear form was approximately $3,200 \mathrm{bp}$ long. It is also clear that the double-stranded or S1 nuclease-resistant linear DNA was elongated (from an average of 2,400 to $3,200 \mathrm{bp}$ ) and the molecular lengths made more homogeneous during the DNA polymerase reaction (compare Fig. $1 B$ and D).

Acrylamide gel electrophoresis of restriction endonuclease digests. The DNA fragment patterns produced by restriction endonuclease digestion of unelongated and elongated Dane particle DNA are shown in Fig. 2. The pattern produced by Hae III and visualized by ethidium bromide staining (Fig. 2B) was similar to that found by Summers et al. (23), using DNA labeled in vitro. We did note certain differences, the significance of which is not clear: the gradient acrylamide gel system resolved the $\mathrm{A}$ band into two bands of equal intensity, here called $A$ and $\mathbf{A}^{\prime}$, which differed by approximately $30 \mathrm{bp}$; we did not observe discrete bands corresponding to the $\mathrm{B}, \mathrm{G}, \mathrm{L}$, or $\mathrm{M}$ band of Summers et al. by ethidium bromide stain. Fully elongated DNA labeled in vitro by the "nick translation" technique of Rigby et al. (15) revealed a similar Hae III digest pattern (Fig. $2 C$ ), with the addition of a band at G. (On other gels, not shown, the A-A' doublet was visible.) In both ethidium-stained gels and the autoradiograms of radioactive DNA digests, numerous minor bands were also observed. These substoichiometric bands were homogeneous and thus probably not due to incomplete digestion. Several additional observations also suggest that the Hae III reaction went to completion. In all experiments, parallel digestions of SV40 DNA in equivalent or greater amounts in the same buffer went to completion in all cases. Increasing the concentration of Hae III and extending the reaction time to as long as $8 \mathrm{~h}$ did not change the pattern of Hae III fragments observed on gels. The minor bands resulting from Hae III digestion of Dane particle DNA included several bands in the range of $B$ (Fig. 3C) and one the size of G (Fig. 2C). These minor bands as well as all of the major bands described were also present in DNA from preparations of Dane particles further purified by equi- librium centrifugation in sucrose density gradients, suggesting that they were associated with Dane particles and not material contaminating the preparation. The sum of fragment sizes, including $\mathrm{A}^{\prime}$ but omitting $\mathrm{B}, \mathrm{G}$, and the minor bands, was $3,850 \mathrm{bp}$, significantly larger than the size of the undigested DNA molecules observed on agarose gels. The sum of fragment sizes including $\mathrm{G}$ and $\mathrm{B}$ was $4,910 \mathrm{bp}$. Adding the minor bands would make the sum even greater. Visual comparison of the elongated and unelongated DNA digests suggests that fragments $\mathrm{D}, \mathrm{F}, \mathrm{H}, \mathrm{J}$, and $\mathrm{K}$ were underrepresented in the unelongated molecules.

Endonuclease $\mathrm{Hin}$ II produced five major fragments (Fig. 2D and E); the largest two formed a doublet slightly larger than Hae III A$\mathrm{A}^{\prime}$, and the two differed from each other by about $30 \mathrm{bp}$. Endogenous polymerase-labeling experiments (see below, Fig. 4) indicated that the two components of the doublet came from the same portion of the DNA molecule. The sum of the lengths of the Hin II fragments was approximately $3,600 \mathrm{bp}$. Visually, only band B (which may actually be a group of bands) appeared to be deficient in the unelongated DNA.

Endonuclease Hinf cleaved the DNA into 10 discrete major bands and numerous minor bands (Fig. 2F and G). The sum of lengths of the major bands was about $2,500 \mathrm{bp}$; the assortment of minor bands between A and B could add 400 to $1,500 \mathrm{bp}$ to the total. Bands A, C, D, and $\mathrm{H}$ were reduced in the unelongated DNA.

Endonuclease EcoRI digestion of the DNA generated an ambiguous pattern (not shown), with at least three large pieces $(1,200$ to 1,400 bp) and a number of smaller pieces. The Dane particle DNA did not contain any cleavage sites for endonuclease $\mathrm{Hin}$ III.

Location and rate of endogenous DNA synthesis. The site of initiation of the endogenous DNA polymerase was examined by analysis of short pulse and pulse-chase synthesis; the product was isolated, digested by restriction endonucleases, and electrophoresed on acrylamide gradient gels. Under pulse conditions, the rate of DNA synthesis was found to be constant and in the range of 5 to 10 nucleotides per min per DNA molecule for the first $10 \mathrm{~min}$. This is a minimum estimate, since it is possible that not all of the DNA molecules participated in the reaction; however, it should be a reasonable estimate since, as shown in Fig. 1C and D, ultimately all DNA molecules were fully elongated.

When DNA synthesis was terminated after $10 \mathrm{~min}$ (50 to 100 nucleotides), ${ }^{32} \mathrm{P}$ was found in Hae III fragments C, D, E, I, and K, with traces 


\section{A $\frac{\text { Hae III }}{\text { B }}$}

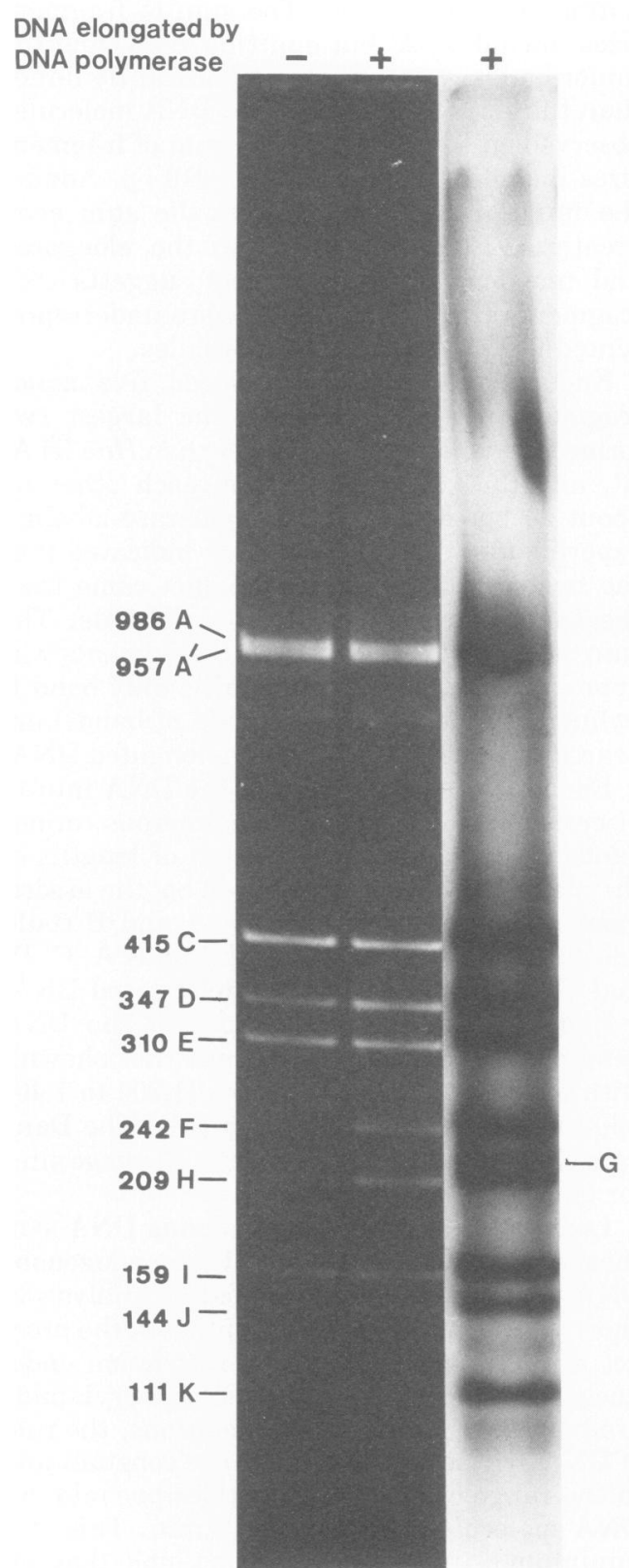

$\frac{\text { Hin II }}{\text { D E }}$
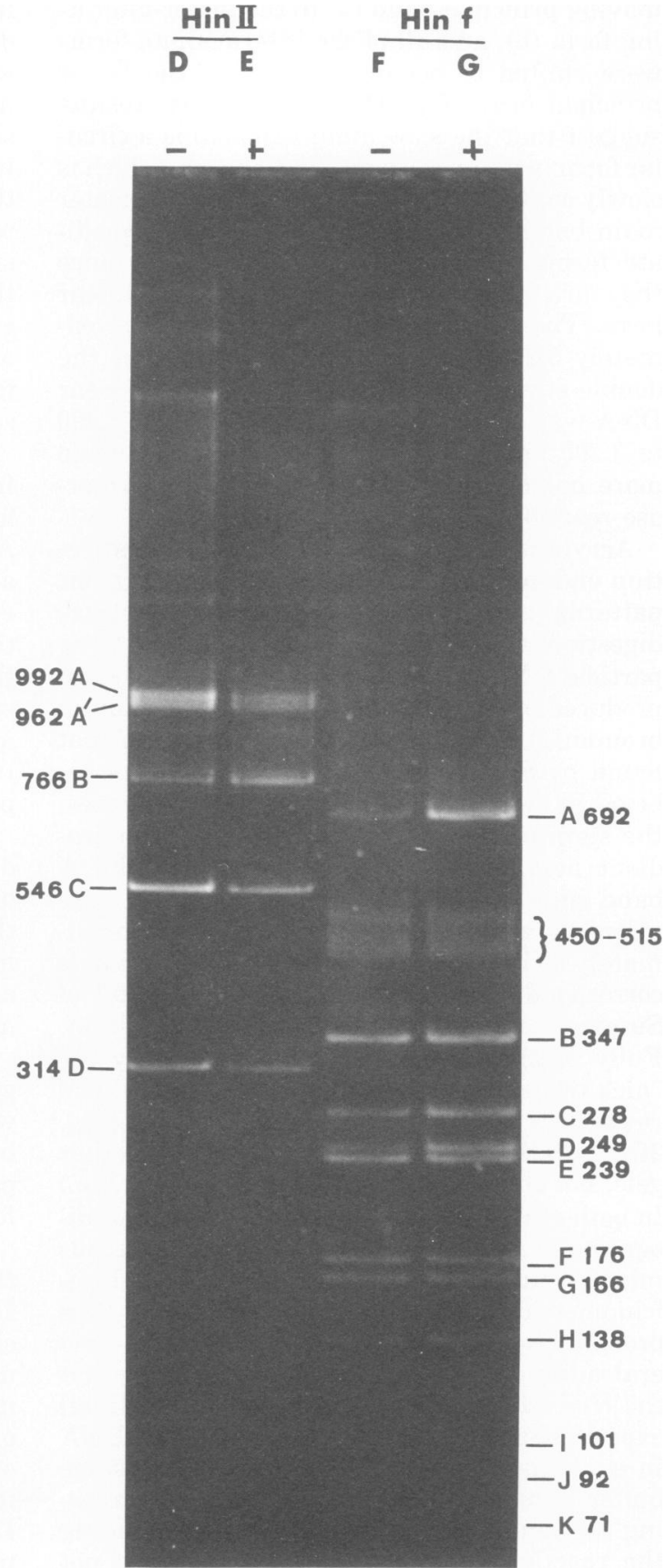

FIG. 2. Restriction endonuclease fragments of Dane particle DNA.

in $\mathrm{F}$ and $\mathrm{H}$ as well as other nonstoichiometric bands (Fig. 3B and D). In these experiments a small amount of DNA (not detected by ethidium bromide) containing a major portion of the incorporated ${ }^{32} \mathrm{P}$ was found in an aggregate near the top of the gel. This aggregate could not be disrupted by an additional cycle of protein- ase $\mathrm{K}$ digestion (Fig. $3 \mathrm{E}$ ). After $3 \mathrm{~h}$ of DNA synthesis, distribution of ${ }^{32} \mathrm{P}$ was essentially identical to that observed at $10 \mathrm{~min}$, except that no aggregate was observed and a small amount of radioactivity appeared in A-A' (Fig. $3 \mathrm{~A}$ and C). Some radioactivity was observed in a location corresponding to the Hae III $\mathrm{B}$ band of 
$3 \mathrm{hr} 10 \mathrm{~min} 3 \mathrm{hr} 10 \mathrm{~min} 10 \mathrm{~min}$

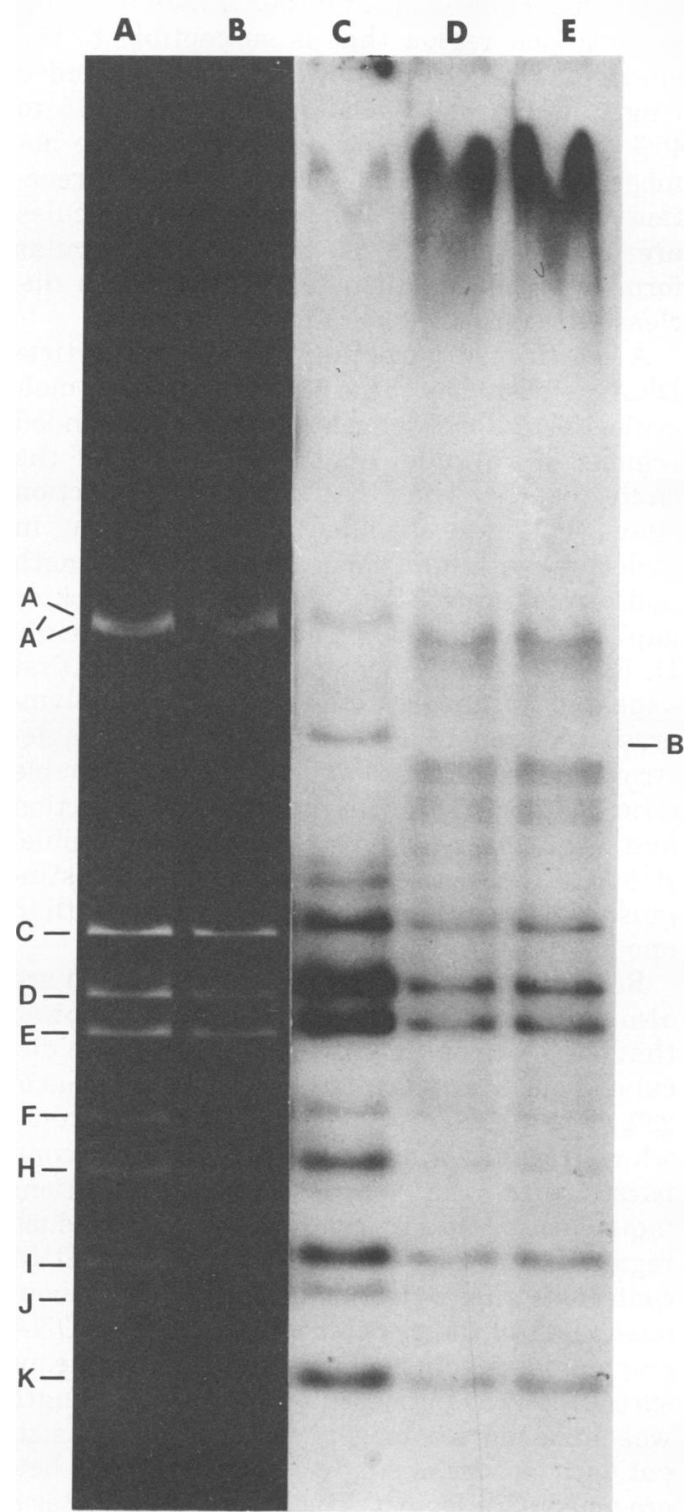

Fig. 3. Restriction endonuclease Hae III fragments after different DNA polymerase reaction times.

Summers et al. (23), but no ethidium bromide fluorescence was detected at that gel position. The extent of labeling correlated approximately with the increased fluorescence of bands after long synthesis with the exception of bands $F$ (less label than expected) and I (more than expected).

The distribution of ${ }^{32} \mathrm{P}$ after a 5 -s pulse followed by a 3-h chase (Fig. 4B and D) was essentially the same as that seen at 10 min (Fig. $3 \mathrm{C}$ ) and $3 \mathrm{~h}$ (Fig. $4 \mathrm{~A}$ and $\mathrm{C}$ ). (On the original autoradiogram, bands visible in track $\mathrm{B}$ were $\mathrm{Hae}$ III C, D, E, H, I, and $\mathrm{K}$; in track D, Hin II B, C, and $\mathrm{D}$ were labeled.) The similar extent of la- beling of Hae III A and $\mathrm{A}^{\prime}$ and Hin II A and $\mathrm{A}^{\prime}$ suggests that those fragments probably overlap extensively in sequence. The very large labeled fragments observed in the Hin II digest after a 3 -h reaction did not correspond to any DNA detectable by fluorescence.

In other experiments (not shown), Hinf fragments A, B, C, D, E, and $\mathrm{H}$ were labeled by the endogenous polymerase in rough proportion to their increase in fluorescence intensity after full elongation (e.g., Fig. $2 \mathrm{~F}$ and G). No radio-
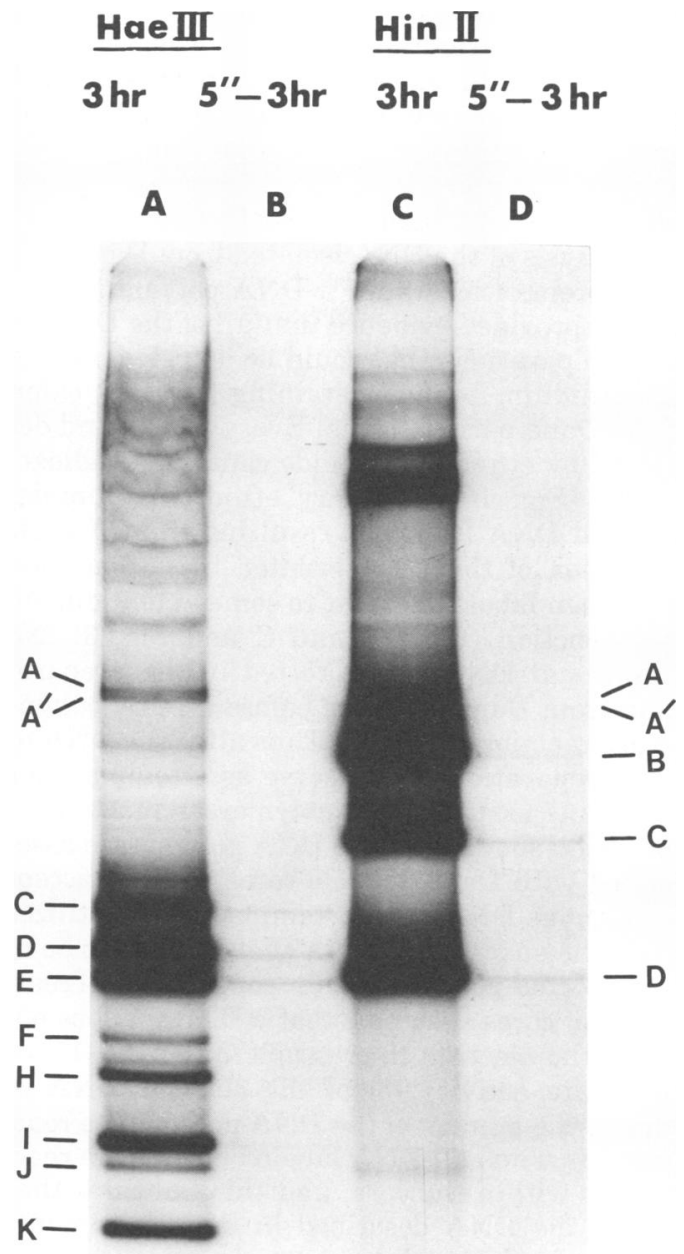

Fig. 4. Autoradiographs of restriction endonuclease DNA fragments after different DNA polymerase reaction times. 
activity was found in the region of diffuse bands between $\mathrm{A}$ and $\mathrm{B}$.

\section{DISCUSSION}

All of the DNA used in these studies was extracted from partially purified Dane particle preparations and further purified by sedimentation in sucrose density gradients. The circular DNA molecules in Dane particle cores, which serve as a template for the endogenous DNA polymerase reaction, sediment as a homogeneous band (15S) in neutral sucrose gradients (17), and after a reaction with ${ }^{32} \mathrm{P}$-labeled nucleotides the DNA is easily located in a sucrose gradient by its radioactivity. To determine the position of unreacted Dane particle DNA in sucrose gradients, a small amount of radioactive Dane particle DNA (too little to be detected by ethidium bromide) was added to serve as a sedimentation marker. This method of purification would eliminate any DNA that might still contaminate the final Dane particle preparation and that differed from Dane particle DNA in sedimentation coefficient.

Analysis of the DNA isolated from Dane particle preparations after a DNA polymerase reaction provided evidence that all of the DNA in our preparations that could be detected on gels by ethidium bromide staining actually came from Dane particle cores. Every DNA band detected by ethidium bromide contained radioactivity (Fig. 1C-F). Every ethidium bromidestained DNA fragment resulting from $\mathrm{Hae}$ III digestion of the DNA isolated by our method had been labeled at least to some extent during the reaction (Fig. $2 \mathrm{~B}$ and $\mathrm{C}$ and Fig. 3). No additional DNA was detected in the preparation from Dane particles before a DNA polymerase reaction (Fig. 1A). Thus all of the DNA in our preparations could serve as a template for the Dane particle DNA polymerase reaction. It has been shown that the DNA polymerase associated with Dane particle cores will not accept exogenous DNA primer/templates, but utilizes only the endogenous DNA that appears to be in a protected position within the core (8). Treatment of cores with pancreatic DNase I does not alter the electron microscopic integrity (17) or template activity (8) of the circular DNA or digest the product of the DNA polymerase reaction (8). Thus all DNA labeled during the reaction is within the core, and this indicates that all of the DNA described in our experiments was derived from Dane particle cores.

The DNA as packaged in Dane particles is electrophoretically heterogeneous, indicating heterogeneity in molecular size (Fig. 1A). The change in electrophoretic mobility after nu- clease S1 digestion (Fig. 1B) suggests that circular molecules contain either a nick or a single-stranded region that is susceptible to the enzyme. The S1-resistant or double-stranded length of the molecules is increased by 15 to 45\% (average, 25\%) and made much more homogeneous during the DNA polymerase reaction (Fig. 1B and D). The full-length molecules are approximately $3,200 \mathrm{bp}$, and the circular form after the reaction, as before, has a nuclease S1-sensitive site (Fig. 1C and D).

A postulated structure for Dane particle DNA suggested by these results is circular molecules of uniform length with single-stranded regions of variable length (15 to $45 \%$ of the circle length). The DNA polymerase reaction closes the single-stranded region, resulting in molecules with uniform double-stranded length and a remaining S1-susceptible site (a nick or gap). The fact that Hae III-generated fragments $\mathrm{D}, \mathrm{F}, \mathrm{H}, \mathrm{J}$, and $\mathrm{K}$ increased in amount or first appeared in the DNA only after a DNA polymerase reaction is also consistent with singlestranded regions that are made double stranded during the DNA polymerase reaction and result in new Hae III-generated doublestranded fragments. Our results do not distinguish whether there is only one or more than one single-stranded region per molecule.

Recent experiments by Hruska et al. (7) are also consistent with this model. They showed that the electron microscopic length of the circular molecules was increased by an average of 23\% when DNA was spread in formamide, which extends single-stranded regions, compared with the lengths under conditions (aqueous spreading) that do not extend such regions. This suggests that the circular DNA contains a single-stranded region that is about one-fourth of the circular length. After a DNA polymerase reaction, the mean length (aqueous spreading) was increased by $27 \%$ and the length was made more homogeneous, findings consistent with closure of single-stranded regions heterogeneous in length. The mean length after a DNA polymerase reaction corresponded to approximately $3,150 \mathrm{bp}$, in close agreement with the size estimate made here $(3,200 \mathrm{bp})$ by gel electrophoresis.

Summers et al. (23) came to a similar conclusion about the structure of Dane particle DNA and the action of the endogenous DNA polymerase. Their evidence for a single-stranded region was the observation that avian myeloblastosis virus DNA polymerase, which contains no exonuclease activity and thus cannot introduce radioactive nucleotides into preexisting doublestranded DNA, successfully used the Dane par- 
ticle DNA as a primer for DNA synthesis, presumably using single-stranded regions in the DNA as a template. Because the endogenous DNA polymerase activity in Dane particles was said to introduce radioactive nucleotides into the same restriction endonuclease $\mathrm{Hae}$ III-generated DNA fragments as did the avian myeloblastosis virus DNA polymerase, they concluded that the endogenous Dane particle enzyme used the same single-stranded regions as template. The published data, however, show radioactivity in almost all Hae III fragments after a reaction with either polymerase, suggesting that both enzymes introduced radioactive nucleotides into all parts of the circular molecule and not into specific regions. The latter result is consistent with other mechanisms for the endogenous DNA polymerase reaction as well as the possibility that single-stranded gaps in the circular molecules are filled in during the reaction.

The restriction endonuclease digests of Dane particle DNA preparations contained a limited number of homogeneous major fragments (Fig. 2 and 3), indicating a limited amount of unique base sequence in these fragments. However, the sum of sizes of the 10 major fragments detected by ethidium bromide $(3,880 \mathrm{bp})$ and thus the amount of unique DNA in them exceeded the amount of DNA in a single fully elongated DNA molecule $(3,200 \mathrm{bp})$. Two additional fragments (B and $G$ ) detected only by autoradiography after an endogenous DNA polymerase reaction with radioactive nucleotides made the total 4,910 bp. This suggests that the DNA molecules in Dane particles are not all identical in base sequence. This heterogeneity, however, involves a limited amount of unique DNA. Such heterogeneity has not been described for other viral DNAs.

In addition, numerous minor fragments in restriction endonuclease digests indicate the presence of a minor component of very heterogeneous DNA similar to that observed in the DNA of some "high-multiplicity" defective viruses (11).

The Dane particle DNA polymerase reaction introduces significant radioactivity into all major fragments in the Hae III (and Hin II) digests except Hae III A-A' (and Hin A-A'), which is only lightly labeled. The sum of the sizes of the fragments that are heavily labeled is 1,550 to $1,600 \mathrm{bp}$, or one-third to one-half of the fulllength molecule. After very short reaction times ( $5 \mathrm{~s}$ or $10 \mathrm{~min}$ ), at least some radioactivity was found in all of the fragments heavily labeled at $3 \mathrm{~h}$ even though very limited DNA synthesis had taken place after short pulses.
The rate of chain growth under these reaction conditions was only 5 to 10 nucleotides per min. This indicates that DNA synthesis is initiated at variable sites over the entire region (onethird to one-half of the molecule) where DNA synthesis eventually takes place. Thus the single-stranded region in different molecules must exist at different sites in the molecule or, alternately, there is more than one single-stranded region (and initiation site for DNA synthesis) per molecule.

The biological utility of a circular DNA that is single stranded over one-third of its length and a virion enzyme that closes the singlestranded region for a virus such as HBV is not clear. Such features have not been described for other viruses.

\section{ACKNOWLEDGMENTS}

This work was supported by Public Health Service research grant AI-13526 from National Institute of Allergy and Infectious Diseases. T.A.L. was a fellow of the Jane Coffin Memorial Fund for Medical Research. H.B.G. was the recipient of Public Health Service postdoctoral training grant 1-F-32-AM 05278 from the National Institute of Arthritis, Metabolism and Digestive Diseases.

\section{LITERATURE CITED}

1. Almeida, J. D. 1972. Individual morphological variation seen in Australia antigen positive sera. Am. J. Dis. Child. 123:303-309.

2. Almeida, J. D., D. Rubenstein, and E. J. Stott. 1971 New antigen antibody system in Australia antigen positive hepatitis. Lancet ii:1225-1227.

3. Alter, H. J., L. B. Seeff, P. M. Kaplan, V. J. McAuliffe, E. C. Wright, J. L. Gerin, R. H. Purcell, P. V. Holland, and H. J. Zimmerman. 1976. Type B hepatitis: the infectivity of blood positive for e antigen and DNA polymerse after accidental needlestick exposure. N. Engl. J. Med. 295:909-913.

4. Barker, L. F., and R. Murray. 1972. Relationship of virus dose to incubation time of clinical hepatitis and time of appearance of hepatitis-associated antigen. Am. J. Med. Sci. 263:27-33.

5. Dane, D. S., C. H. Cameron, and M. Briggs. 1970. Virus-like particles in serum of patients with Australia antigen associated hepatitis. Lancet ii:695-698.

6. Greene, P. J., M. C. Betlach, H. M. Goodman, and H. W. Boyer. 1974. The EcorI restriction endonuclease, p. 76-111. In R. B. Wickner (ed.), Methods in Molecular Biology. Marcel Dekker Inc., New York.

7. Hruska, J. F., D. A. Clayton, J. L. R. Rubenstein, and W. S. Robinson. 1977. Structure of hepatitis B Dane particle DNA before and after the Dane particle DNA polymerase reaction. J. Virol. 21:666-682.

8. Kaplan, P. M., R. L. Greenman, J. L. Gerin, R. H. Purcell, and W. S. Robinson. 1973. DNA polymerase associated with human hepatitis B antigen. J. Virol. 12:995-1005.

9. Krugman, S. 1975. Viral hepatitis type B: prospects for active immunization. Am. J. Med. Sci. 270:391-393.

10. Krugman, S., J. H. Hoofnagle, R. J. Gerety, et al. 1974. Viral hepatitis type B: DNA polymerase activity and core antigen antibody to hepatitis B core antigen. $\mathbf{N}$. Engl. J. Med. 290:1331-1335.

11. Lavi, S., and E. Winocour. 1972. Acquisition of se- 
quences homologous to host DNA by closed circular simian virus 40 deoxyribonucleic acid. J. Virol. 9:309316.

12. McCollum, R. W. 1952. The size of hepatitis virus. Proc. Soc. Exp. Biol. Med. 81:157-163.

13. Middleton, J. H., M. H. Edgell, and C. A. Hutchinson. 1972. Specific fragments of $\phi \times 174$ deoxyribonucleic acid produced by a restriction enzyme from Haemophilus aegyptius, endonuclease Z. J. Virol. 10:42-50.

14. Okada, K., I. Kamiyama, M. Inomata, I. Mitsunobu, Y. Miyakawa, and M. Mayumi. 1976. e Antigen and anti-e in the serum of asymptomatic carrier mothers as indicators of positive and negative transmission of hepatitis B virus to their infants. N. Engl. J. Med. 294:746-749.

15. Rigby, P. W. J., M. Dieckmann, C. Rhodes, and P. Berg. 1977. Labeling deoxyribonucleic acid to high specific activity in vitro by nick translation with DNA polymerase I. J. Mol. Biol., in press.

16. Robinson, W. S. 1975. DNA and DNA polymerase in the core of the Dane particle of hepatitis B. Am. J. Med. Sci. 270:151-159.

17. Robinson, W. S., D. A. Clayton, and R. L. Greenman. 1974. DNA of a human hepatitis B virus candidate. J.
Virol. 14:384-391.

18. Robinson, W. S., and R. L. Greenman. 1974. DNA polymerase in the core of the human hepatitis $B$ virus candidate. J. Virol. 13:1231-1236.

19. Robinson, W. S., and L. I. Lutwick. 1976. Hepatitis B virus: a cause of persistent infection in man, p. 787811. In D. Baltimore, A. Huang, and C. F. Cox (ed.) Animal virology. Academic Press Inc., New York.

20. Robinson, W. S., and L. I. Lutwick. 1976. The virus of hepatitis B. N. Engl. J. Med. 295:1168-1175, 12321236.

21. Shenk, T. E., C. Rhodes, P. W. J. Rigby, and P. Berg. 1975. Biochemical method for mapping mutational alterations in DNA with S1 nuclease: the location of deletions and temperature-sensitive mutations in Simian Virus 40. Proc. Natl. Acad. Sci. U.S.A. 72:989-993.

22. Smith, H. O., and K. W. Wilcox. 1970. A restriction enzyme from Hemophilus influenzae. I. Purification and general properties. J. Mol. Biol. 51:379-391.

23. Summers, J. A., A. O'Connel, and I. Millman. 1975. Genome of hepatitis B virus: restriction enzyme cleavage and structure of DNA extracted from Dane particles. Proc. Natl. Acad. Sci. U.S.A. 72:4597-4601. 